\title{
Study the Association of Demographic Factors and Occupational Injuries, Health Hazards of Plant Nursery Workers
}

\author{
J. Deepika ${ }^{1 *}$, P. Radha Rani ${ }^{1}$, V. Vijaya Lakshmi ${ }^{2}$, R. Neela Rani ${ }^{3}$ and A. Dhandapani ${ }^{4}$ \\ ${ }^{1}$ Department of Resource Management and Consumer Sciences, College of Home Science, \\ PJTSAU, Hyderabad, India \\ ${ }^{2}$ FRM -AICRP (Home Science), PJTSAU, Hyderabad, India \\ ${ }^{3}$ Department of Home Science and Extension Education, College of Home Science, PJTSAU, \\ Hyderabad, India \\ ${ }^{4}$ Department of Statistics/Computer Applications, National Academy of Agricultural Research \\ Management, Rajendranagar, Hyderabad, India \\ *Corresponding author
}

\section{A B S T R A C T}

The main objective of the study was to determine the association of demographic factors to occupational injuries, health hazards of nursery workers. This study was conducted at

\section{Keywords}

Nursery workers,

Demographic

factors, Occupation

injuries, Health

hazards, Pain relief

\section{Article Info}

Accepted:

07 April 2019

Available Online:

10 May 2019 various plant nursery business areas and a total sample of 120 nursery workers were selected through the simple random technique. Data was analysed by using SPSS software and Microsoft Excel 2010. Frequencies, percentage and Chi-square test were performed to detect the statistical significance. Results revealed that majority $(67.50 \%)$ of the workers belonged to the age group between $27-45$ years and more than half of the them $(54.17 \%)$ were male workers. Most of the workers were married $(75 \%)$ and 39.17 per cent of the workers had completed their education up to primary level. Maximum (52.50\%) number of the workers was having 5-8 years experience. Nursery workers frequently injured with wounds or cuts and lacerations due to sharp tools whereas majority of the nursery workers were suffered frequently with dizziness, weakness and numbness and was found significant association between age and occupational injuries and it also found a significant association between occupational health hazards and selected variables Viz., age, marital status, educational qualification, number of years of work experience and work pattern and no association between occupational health hazards and gender.

\section{Introduction}

An occupation is a normal activity performed for money, survive for family gain and profit, to fulfill their requirements and to lead a financially secured life. Occupational health is concerned with health of the workers in its relation to work and working environment (!). Based on the working conditions and working environment, nursery workers are exposed to a wide variety of health hazards at work. The occupation of the workers will differ and exposed to multiple physical, chemical and biological agents and multi-factorial causes 
which make them vulnerable to various health problems that include musculoskeletal disorders, injuries, health hazards and respiratory problems (Brindha, 2005).

The labour workforce is more susceptible to many occupational injuries and health hazards. Quirina et al., (2008) reported that majority of the farm women experienced skin problem, pimples, or acne, rash, including skin sunburn; itching and insect bite on different parts of the body whereas Defar and Ali (2013) investigated on floriculture workers and had reported skin problem and respiratory health, fatigue, head ache and sleepiness. Kaur and Sharma (2009), wherein it was reported that there was a lack of awareness regarding the right body postures and sometimes, due to lack of rest pauses in between which is essential to recoup from body stress.

Hence this study was carried out in plant nursery business to study the association between socio-demographic factors and occupational injuries and health hazards of the plant nursery workers.

\section{Materials and Methods}

Exploratory research design was selected for the study. A simple random sampling technique was used to select plant nursery workers. A total of 120 plant nursery workers from twin cities of Telangana i.e., Hyderabad and Secunderabad were selected for the study. Interview schedule was used for data collection. Frequencies, percentages and chisquare were used for analyzing the data by using SPSS software and Microsoft Excel 2010.

\section{Results and Discussion}

The results of the present study were presented below
The socio-demographic characteristics of the nursery workers were studied. Majority $(67.50 \%)$ of the workers belonged to the age group between 27-45 years and more than half of the them $(54.17 \%)$ were male workers. Most of the workers were married $(75 \%)$ and 39.17 per cent of the workers had completed their education up to primary level. Maximum $(52.50 \%)$ number of the workers was having 5-8 years experience.

Majority (79.17\%) of the workers belonged to medium sized family members and fit into nuclear family (97.50\%) and most of the workers belonged to semi-urban (56.67\%).

As illustrated from table 1, it is clear that higher percentage of nursery workers injured frequently with wounds or cuts and lacerations due to sharp tools $(29.17 \%)$ followed by sprains and strains (10.83\%), fractures $(9.17 \%)$, falls from slippery and uneven surfaces $(6.67 \%)$, bruises and contusions $(5.83 \%)$. Least percentage $(4.17 \%)$ of nursery workers was injured frequently with poisonous insect bites and stings.

With regard to occupational health hazards of nursery workers, majority of the nursery workers had suffered frequently with dizziness, weakness, numbness, tingling, giddiness $(25.83 \%)$, Difficulty swallowing, headaches (21.67\%), Current low back pain, other joint swelling or muscle pain $(20.00 \%)$ and Nausea, vomiting, loss of control of stools (5.83\%). Equal percentage of nursery workers frequently suffering with fever, unintentional weight change, new rashes or psoriasis or skin lesions with 4.17 per cent whereas loss of control of urine/urine frequency or urgency, depressed mood, sleep problems, anxiety with 3.33 per cent. Least percentage of nursery workers were suffering frequently with shortness of breath, wheezing, cough $(2.50 \%)$ and chest pain, palpitations (1.67\%) (Table 2). 
From the table 3 , it is clear that hundred per cent of nursery workers were suffered due to over exertion, illness/exhausted and also based on work they could perform the activity for long hours, continuous and forceful movement and repetitively with hands, wrists and shoulder. Apart from these reasons nursery tools handle shape and size was not proper $(97.50 \%)$ were the common reasons for accidents.

Physical Strain and fatigue (96.67\%), long hours of bending and squatting postures $(95.00 \%)$, lack of knowledge $(90.00 \%)$ were the common reasons for health hazard. More or less percentage of nursery workers expressed the reasons such as due to negligence $(86.67 \%)$, carrying heavy load $(85.00 \%)$ and due to exposure to dust $(76.67 \%)$.

It is clear from the above Figure 1 that utmost percent $(100 \%)$ of nursery workers adopted balms, ayurvedic oils, tablets and medicines prescribed by a doctor followed by medicines for indigestion (82.50\%), blood pressure tablets $(23.33 \%)$ and pain killers $(7.50 \%)$.

The findings from the table 4 revealed that majority of the nursery workers were using balms and ayurvedic oils and tablets daily whereas none of the nursery workers were using sleeping pills.

Occupational injuries of the nursery workers were selected and studied the association between occupational injuries and selected independent variables Viz., age, gender, marital status, educational qualification, number of years of work experience and work pattern of nursery activities and was found that there was no association between gender, marital status, educational qualification, number of years of work experience and work pattern and occupational injuries of the nursery workers whereas it was highly significant association was found between age and occupational injuries (Table 5).

The association between occupational health hazards and selected independent variables was selected and studied, there was significant association was found between occupational health hazards and selected variables Viz., age, marital status, educational qualification, number of years of work experience and work pattern and no association between occupational health hazards and gender (Table 6).

Table.1 Occupational injuries of nursery workers at workplace $n=120$

\begin{tabular}{|c|c|c|c|}
\hline \multirow{3}{*}{ Occupational injuries } & \multirow{2}{*}{\multicolumn{3}{|c|}{ Frequency }} \\
\hline & & & \\
\hline & $\begin{array}{c}\text { Never } \\
1\end{array}$ & $\begin{array}{c}\text { Sometimes } \\
2\end{array}$ & $\begin{array}{c}\text { Frequently } \\
3\end{array}$ \\
\hline Wound/Cuts and lacerations due to sharp tools & $22(18.33 \%)$ & $63(52.50 \%)$ & $35(29.17 \%)$ \\
\hline Fractures & $72(60.00 \%)$ & $37(30.83 \%)$ & $11(9.17 \%)$ \\
\hline Sprains and strains & $50(41.67 \%)$ & $57(47.50 \%)$ & $13(10.83 \%)$ \\
\hline Bruises and contusions & $66(55.00 \%)$ & $47(39.17 \%)$ & $7(5.83 \%)$ \\
\hline Burns and Heat cramps & $106(88.33 \%)$ & $14(11.67 \%)$ & -- \\
\hline Falls from slippery and uneven surfaces & $25(20.83 \%)$ & $87(72.50 \%)$ & $8(6.67 \%)$ \\
\hline Poisonous insect bites and stings & $77(64.17 \%)$ & $38(31.67 \%)$ & $5(4.17 \%)$ \\
\hline
\end{tabular}


Table.2 Occupational health hazards of nursery workers $n=120$

\begin{tabular}{|l|c|c|c|}
\hline \multicolumn{3}{|c|}{ Frequency } \\
\hline \multirow{2}{*}{ Occupational health hazards } & \multicolumn{3}{|c|}{ N=120 } \\
\cline { 2 - 4 } & Never & $\begin{array}{c}\text { Sometimes } \\
\text { Fever, unintentional weight change }\end{array}$ & $\begin{array}{c}\text { Frequently } \\
3\end{array}$ \\
\hline Vision change, double vision & $53(44.17 \%)$ & $62(51.67 \%)$ & $5(4.17 \%)$ \\
\hline Difficulty swallowing, headaches & $66(55.00 \%)$ & $54(45.00 \%)$ & - \\
\hline Chest pain, palpitations & $48(40.00 \%)$ & $46(38.33 \%)$ & $26(21.67 \%)$ \\
\hline Shortness of breath, wheezing, cough & $90(75.00 \%)$ & $28(23.33 \%)$ & $2(1.67 \%)$ \\
\hline Nausea, vomiting, loss of control of stools & $87(72.50 \%)$ & $30(25.00 \%)$ & $3(2.50 \%)$ \\
\hline $\begin{array}{l}\text { Loss of control of urine/urine frequency or } \\
\text { urgency }\end{array}$ & $81(67.50 \%)$ & $32(26.67 \%)$ & $7(5.83 \%)$ \\
\hline New rashes or psoriasis or skin lesions & $68(56.17 \%)$ & $27(22.50 \%)$ & $4(3.33 \%)$ \\
\hline Dizziness, weakness, numbness, tingling, giddiness & $76(63.33 \%)$ & $47(39.17 \%)$ & $5(4.17 \%)$ \\
\hline Depressed mood, sleep problems, anxiety & $81(67.50 \%)$ & $35(29.17 \%)$ & $41(25.83 \%)$ \\
\hline $\begin{array}{l}\text { Current low back pain, other joint swelling or } \\
\text { muscle pain }\end{array}$ & $55(45.83 \%)$ & 41 & $24(20.00 \%)$ \\
\hline
\end{tabular}

Table. 3 Reasons for occupational injuries and health problems of nursery workers $n=120$

\begin{tabular}{|c|c|c|}
\hline \multirow{3}{*}{ Variables } & \multicolumn{2}{|r|}{$\mathrm{N}=\mathbf{1 2 0}$} \\
\hline & \multicolumn{2}{|c|}{ Grade of opinions } \\
\hline & No & Yes \\
\hline Lack of knowledge & $12(10.00 \%)$ & $108(90.00 \%)$ \\
\hline Over exertion & - & $120(100 \%)$ \\
\hline Physical Strain and fatigue & $4(3.33 \%)$ & $116(96.67 \%)$ \\
\hline Continuous and forceful movement & - & $120(100 \%)$ \\
\hline Due to illness/exhausted & - & $120(100 \%)$ \\
\hline Long hours of hard work & - & $120(100 \%)$ \\
\hline Repetitive movements in hand, shoulder, wrist & - & $120(100 \%)$ \\
\hline Bedding and awkward posture & - & $120(100 \%)$ \\
\hline Static posture & $9(7.50 \%)$ & $111(92.50 \%)$ \\
\hline Tools handle shape and size not proper & $3(2.50 \%)$ & $117(97.50 \%)$ \\
\hline Carrying heavy load & $18(15.00 \%)$ & $102(85.00 \%)$ \\
\hline Long hours of bending and squatting postures & $6(5.00 \%)$ & $114(95.00 \%)$ \\
\hline Exposure of dust & $28(23.33 \%)$ & $92(76.67 \%)$ \\
\hline Due to negligence & $16(13.33 \%)$ & $104(86.67 \%)$ \\
\hline
\end{tabular}


Table.4 Adoptive measures for pain relief $n=120$

\begin{tabular}{|l|c|c|c|c|c|}
\hline & \multicolumn{5}{|c|}{ Frequency pattern of adoptive measures } \\
\hline & Never & $\begin{array}{c}\text { Twice in a } \\
\text { month }\end{array}$ & $\begin{array}{c}\text { Once in a } \\
\text { month }\end{array}$ & $\begin{array}{c}\text { Once in a } \\
\text { week }\end{array}$ & Daily \\
\cline { 2 - 7 } & 1 & 2 & 3 & 4 & 5 \\
\hline Medicines for indigestion & $21(17.50 \%)$ & $72(60.00 \%)$ & $16(13.33 \%)$ & $11(9.17 \%)$ & - \\
\hline Pain killers & $111(92.50 \%)$ & $3(2.50 \%)$ & $3(2.50 \%)$ & $3(2.50 \%)$ & - \\
\hline Blood pressure tablets & $92(76.67 \%)$ & $28(23.33 \%)$ & - & - & - \\
\hline $\begin{array}{l}\text { Balms, Ayurvedic oils, } \\
\text { tablets }\end{array}$ & $3(2.50 \%)$ & $8(6.67 \%)$ & $2924.17 \%)$ & $15(12.50 \%)$ & $65(54.17 \%)$ \\
\hline Sleeping pills & $120(100 \%)$ & - & - & - & - \\
\hline $\begin{array}{l}\text { Other medicines } \\
\text { prescribed by a doctor }\end{array}$ & - & - & $120(100 \%)$ & - & - \\
\hline
\end{tabular}

Table.5 Association between occupational injuries at workplace and selected variables of the study

\begin{tabular}{|l|c|c|c|c|c|c|}
\hline & Age & Gender & $\begin{array}{c}\text { Marital } \\
\text { status }\end{array}$ & $\begin{array}{c}\text { Educational } \\
\text { qualification }\end{array}$ & $\begin{array}{c}\text { work } \\
\text { experience }\end{array}$ & $\begin{array}{c}\text { Work } \\
\text { pattern }\end{array}$ \\
\hline$\chi^{\mathbf{2}}$ value & 287.9 & 12.73 & 19.07 & 36.3 & 76.71 & 32.18 \\
\hline $\mathbf{N}$ & 120 & 120 & 120 & 120 & 120 & 120 \\
\hline df & 245 & 7 & 21 & 42 & 77 & 28 \\
\hline $\begin{array}{l}\text { Probability } \\
\text { value }\end{array}$ & $0.031^{*}$ & $0.079^{\text {ns }}$ & $0.580^{\text {ns }}$ & $0.716^{\text {ns }}$ & $0.488^{\text {ns }}$ & $0.267^{\text {ns }}$ \\
\hline Note: * -Significant at probability level of $<$ & $\mathbf{0 . 0 5}$ ns - non significant \\
\hline
\end{tabular}

Table.6 Association between occupational health hazards and selected variables of the study

\begin{tabular}{|l|c|c|c|c|c|c|}
\hline & Age & Gender & $\begin{array}{c}\text { Marital } \\
\text { status }\end{array}$ & $\begin{array}{c}\text { Educational } \\
\text { qualification }\end{array}$ & $\begin{array}{c}\text { work } \\
\text { experience }\end{array}$ & $\begin{array}{c}\text { Work } \\
\text { pattern }\end{array}$ \\
\hline$\chi^{\mathbf{2}}$ value & 493.5 & 8.3 & 70.03 & 98.7 & 143.1 & 65.41 \\
\hline $\mathbf{N}$ & 120 & 120 & 120 & 120 & 120 & 120 \\
\hline df & 350 & 10 & 30 & 60 & 110 & 40 \\
\hline $\begin{array}{l}\text { Probability } \\
\text { value }\end{array}$ & $0.0001^{* *}$ & $0.595^{\text {ns }}$ & $0.0001^{* *}$ & $0.001^{* *}$ & $0.018^{* *}$ & $0.007^{* *}$ \\
\hline Note: **- Significant at probability level of $<\mathbf{0 . 0 1}$ & ns - non significant \\
\hline
\end{tabular}


Table.7 Association between reasons for occupational injuries and health problems and selected variables of the study

\begin{tabular}{|l|c|c|c|c|c|c|}
\hline Variables & Age & Gender & $\begin{array}{c}\text { Marital } \\
\text { status }\end{array}$ & $\begin{array}{c}\text { Educational } \\
\text { qualification }\end{array}$ & $\begin{array}{c}\text { work } \\
\text { experience }\end{array}$ & $\begin{array}{c}\text { Work } \\
\text { pattern }\end{array}$ \\
\hline$\chi^{\mathbf{2}}$ value & 189.6 & 2.45 & 11.18 & 41.57 & 31.38 & 26.82 \\
\hline $\mathbf{N}$ & 120 & 120 & 120 & 120 & 120 & 120 \\
\hline df & 175 & 5 & 15 & 30 & 55 & 20 \\
\hline $\begin{array}{l}\text { Probability } \\
\text { value }\end{array}$ & $0.212^{\mathrm{ns}}$ & $0.783^{\mathrm{ns}}$ & $0.739^{\mathrm{ns}}$ & $0.078^{\mathrm{ns}}$ & $0.996^{\mathrm{ns}}$ & $0.140^{\mathrm{ns}}$ \\
\hline Note: $\mathbf{n s}-$ non significant & & & & & \\
\hline
\end{tabular}

Table.8 Association between adoptive measures for pain relief and selected variables of the study

\begin{tabular}{|c|c|c|c|c|c|c|}
\hline Variables & Age & Gender & $\begin{array}{c}\text { Marital } \\
\text { status }\end{array}$ & $\begin{array}{l}\text { Educational } \\
\text { qualification }\end{array}$ & $\begin{array}{c}\text { work } \\
\text { experience }\end{array}$ & $\begin{array}{l}\text { Work } \\
\text { pattern }\end{array}$ \\
\hline$\chi^{2}$ value & 120.4 & 0.47 & 7.34 & 20.08 & 59.6 & 15.53 \\
\hline $\mathbf{N}$ & 120 & 120 & 120 & 120 & 120 & 120 \\
\hline df & 105 & 3 & 9 & $1 \mathrm{~s} 8$ & 33 & 12 \\
\hline $\begin{array}{l}\text { Probability } \\
\text { value }\end{array}$ & $0.144^{\mathrm{ns}}$ & $0.923^{\mathrm{ns}}$ & $0.601^{\mathrm{ns}}$ & $0.328^{\mathrm{ns}}$ & $0.003^{* *}$ & $0.214^{\mathrm{ns}}$ \\
\hline \multicolumn{7}{|c|}{ Note: $* *$ - Significant at probability level of $<0.01$} \\
\hline
\end{tabular}

Fig.1 Adoptive measures for pain relief

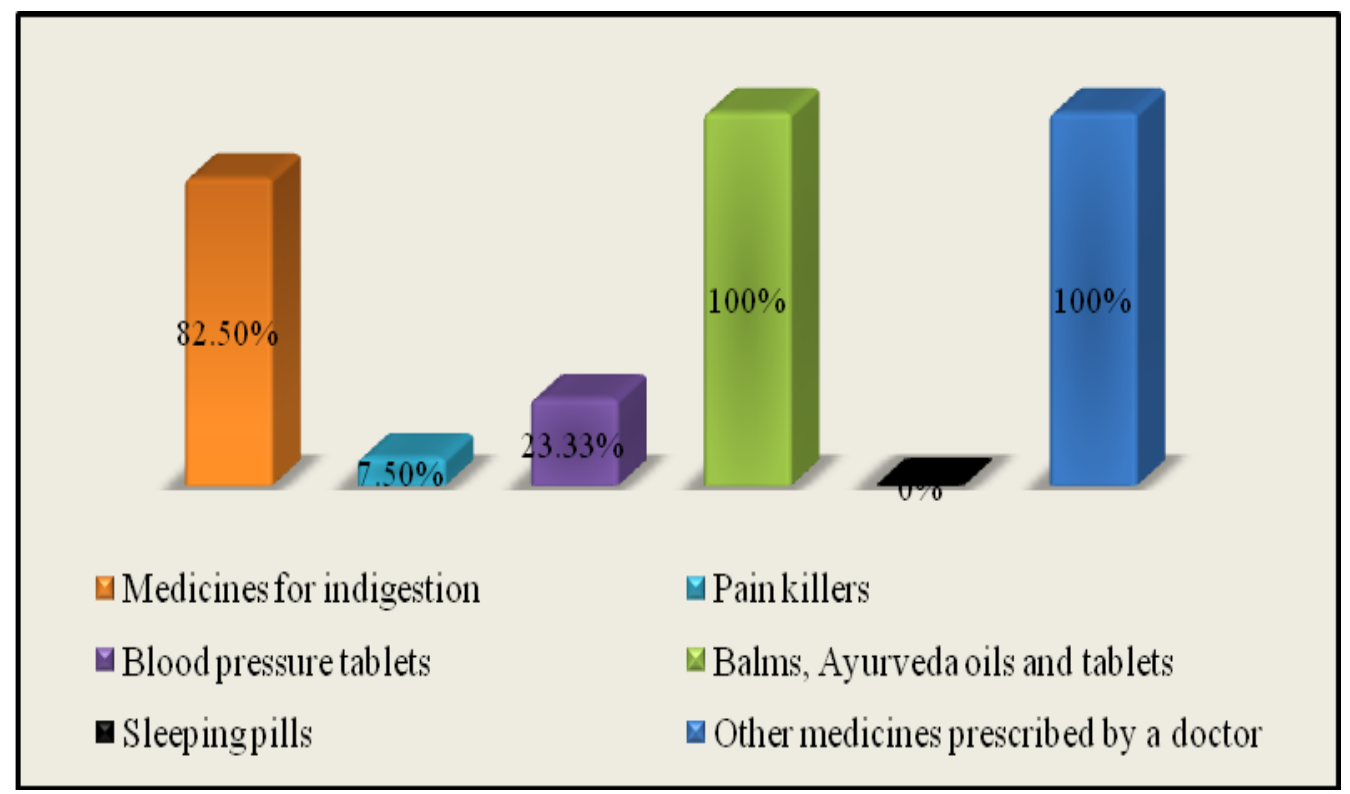


The reasons for occupational injuries and health problems and the selected independent variables were selected and studied and was found that there was no significant association was found between reasons for occupational injuries and health problems and selected independent variables Viz., age, gender, marital status, educational qualification, number of years of work experience and work pattern (Table 7).

Adoptive measures for pain relief and selected independent variables Viz., age, gender, marital status, educational qualification, number of years of work experience and work pattern were selected and studied and was found that there was highly significant association between number of years of work experience of the nursery worker and adoptive measures for pain relief whereas no significant association was found between adoptive measures for pain relief and age, gender, marital status, educational qualification and work pattern of the nursery workers because the number of years of work experienced by the workers was increased their adoptive measures was also increased for relief their pain (Table 8).

From the study, it was concluded that the nursery workers reported many occupational injuries and health hazards occurred while performing different types of nursery activities. The nursery workers frequently injured with wounds or cuts and lacerations due to sharp tools whereas majority of the nursery workers were suffered frequently with dizziness, weakness and numbness. Least percentage of nursery workers were suffering frequently with shortness of breath, wheezing, cough and chest pain, palpitations.. Most of the nursery workers expressed the common reasons for occupational accidents and health hazards such as over exertion, illness/exhausted and also based on work they could perform the activity for long hours, continuous and forceful movement and repetitively with hands, wrists and shoulders. Utmost percent $(100 \%)$ of nursery workers adopted balms, ayurvedic oils, tablets and medicines prescribed by a doctor followed by medicines for indigestion (82.50\%), blood pressure tablets $(23.33 \%)$ and pain killers $(7.50 \%)$. There was highly significant association was found between age and occupational injuries and also found a significant association between occupational health hazards and selected variables Viz., age, marital status, educational qualification, number of years of work experience and work pattern and no association between occupational health hazards and gender.

\section{References}

Brindha, V., 2005.Prevention of occupation health hazards among stone workers. Nightingale nursing times. 1 (9): 17-19.

Quirina, M., Vallejos, M.P.H and Mark, R. 2008. Self report of skin problem among farm workers in North, Carolina. American journal of industrial medicine: 51 (3): 204-212.

Defar, A., and Ali, A. 2013. Occupational induced health problems in floriculture workers in Sebeta and Surrounding areas, West Shewa, Oromia, Ethiopia. Ethiopian journal of health development. 27(1): 64-71.

Kaur, H., and Sharma, S. 2009. Work related body disorders and health hazards faced by farm women of Punjab. International Ergonomic Conference. Humanizing work and work environment. University of Calcutta. Kolkata, India.

\section{How to cite this article:}

Deepika, J., P. Radha Rani, V. Vijaya Lakshmi, R. Neela Rani and Dhandapani, A. 2019. Study the Association of Demographic Factors and Occupational Injuries, Health Hazards of Plant Nursery Workers. Int.J.Curr.Microbiol.App.Sci. 8(05): 505-511. doi: https://doi.org/10.20546/ijcmas.2019.805.060 